\title{
PRODUKSI BAHAN BAKAR CAIR HASIL PIROLISIS MINYAK PELUMAS BEKAS PERTAMBANGAN BATUBARA MENGGUNAKAN KATALIS ZEOLITE
}

\author{
Reno Fitriyanti \\ Dosen Program Studi Teknik Kimia Universitas PGRI Palembang \\ e-mail : renofitriyanti@ymail.com
}

\begin{abstract}
ABSTRAK
Minyak pelumas bekas merupakan limbah otomotif yang masuk dalam kategori limbah berbahaya dan beracun. Pemrosesan minyak pelumas bekas adalah upaya pemanfaatan kembali minyak pelumas bekas serta sebagai alternatif mengurangi kebutuhan bahan bakar cair. Berbagai metode digunakan untuk mengkonversi minyak pelumas bekas menjadi bahan bakar salah satunya yaitu melalui pirolisis. Penelitian ini bertujuan mengetahui pengaruh katalis pada pirolisis minyak pelumas bekas pertambangan batubara terhadap presentase produk cair yang dihasilkan serta mengetahui sifat-sifat fisik produk cair yang dihasilkan. Metode yang dilakukan dalam penelitian ini adalah metode eksperimen dengan menggunakan katalis zeolite masing-masing 0, 1 gr, 2 gr dan 3 gr. Hasil penelitian menunjukkan bahwa pirolisis minyak pelumas bekas dengan katalis zeolit menghasilkan produk cair yang paling lebih banyak dibandingkan pirolisis yang berlangsung tanpa menggunakan katalis. Penggunaan katalis zeolite sebanyak 3 gram menghasilkan produk cair tertinggi yaitu sebesar $75 \%$. Produk cair hasil pirolisis minyak pelumas bekas memiliki sifat-sifat fisik yaitu IBP $190 \mathrm{C}$, densitas $840 \mathrm{gr} / \mathrm{ml}$, viskositas $2,45 \mathrm{~mm}^{2} / \mathrm{s}$, flash point $56 \mathrm{C}$, pour point < 0 , dan spesific gravity 0,840 . Sifat fisik produk cair hasil pirolisis tersebut memenuhi spesifikasi minyak solar pertamina.
\end{abstract}

Kata kunci : minyak pelumas bekas, katalis, zeolite, pirolisis

\section{PENDAHULUAN}

Minyak pelumas (oli) adalah salah satu produk minyak bumi yang masih mengandung senyawa-senyawa aromatik dengan indeks viskositas yang rendah. Hampir semua mesin-mesin dipastikan menggunakan minyak pelumas. Fungsi minyak pelumas adalah mencegah kontak langsung antara dua permukaan yang saling bergesekan, mendinginkan komponen mesin, membantu merapatkan kompresi serta membersihkan komponen mesin. Minyak pelumas memiliki persyaratan antara lain: tahan suhu tinggi, tahan karat dan korosi, mampu mencegah terjadinya busa serta mampu mengalir pada suhu rendah (Arnoldi, 2009). Pertambangan batubara merupakan salah satu sektor yang banyak menggunakan minyak pelumas dalam proses operasional pertambangan dan berpotensi menghasilkan minyak pelumas bekas dalam jumlah besar.

Minyak pelumas bekas merupakan limbah otomotif yang masuk dalam kategori limbah berbahaya dan beracun (B3) (Supriyanto, 2008). Deposit minyak pelumas bekas yang dibuang berlebihan dalam tanah lambat laun akan membentuk emulsi minyak dan air yang dapat menutupi pori-pori dipermukaaan tanah sehingga menghambat resapan air. Dampak lanjutannya adalah terjadinya kontaminasi air tanah yang mengakibatkan pencemaran air tanah dan menghambat proses oksidasi biologi dari sistem lingkungan karena terbunuhnya mikroorganisme yang terdapat didalam tanah. Senyawa hidrokarbon yang terdapat pada oli bersifat toksik dan karsiogenik sehingga 
tumpahan minyak pelumas di permukaan tanah mengakibatkan matinya mikroorganisme yang ada didalam tanah (Zam, 2011). Sifat minyak pelumas yang tidak dapat larut dalam air juga dapat membahayakan habitat air, selain itu sifatnya mudah terbakar yang merupakan karakteristik dari bahan berbahaya dan beracun (B3).

Pemakaian kembali minyak pelumas bekas adalah suatu alternatif dalam menghasilkan sumber-sumber energi. Hasil pengolahan minyak pelumas bekas diharapkan mampu menghasilkan produk yang bermanfaat dan dapat digunakan kembali. Demirbas (2005) menyatakan bahwa minyak pelumas bekas dapat diproses menjadi produk-produk yang dapat digunakan kembali seperti gasoline dan heavy oil.

Askaditya (2010) menyebutkan metode pirolisis merupakan salah satu metode yang dapat digunakan untuk mengolah kembali minyak pelumas bekas menjadi bahan bakar. Dalam menghasilkan produk bahan bakar cair yang bernilai, pirolisis dapat dilaksanakan dengan atau tanpa bantuan katalis. Pada Penelitian ini, proses pirolisis dilakukan dengan memanaskan minyak pelumas hingga temperatur $320 \mathrm{C}$ dan dipanaskan selama satu (1) jam.

Tujuan penelitian ini adalah untuk mengetahui pengaruh katalis pada pirolisis minyak pelumas bekas pertambangan batubara terhadap presentase produk cair yang dihasilkan serta mengetahui sifatsifat fisik produk cair yang dihasilkan dari pirolisis minyak pelumas bekas. Produk cair yang dihasilkan akan dianalisa sifat-sifatnya seperti IBP (initial boiling point), densitas, viskositas, flash point, pour point dan spesific gravity, dimana hasilnya dibandingkan dengan sifat-sifat bahan bakar yang mendekati.

\section{TINJAUAN PUSTAKA}

Minyak pelumas atau oli merupakan sejenis cairan kental yang melumasi bagian-bagian mesin yang saling kontak dan bergerak relatif satu terhadap yang lain, sehingga mencegah terjadinya keausan. Minyak pelumas merupakan salah satu produk minyak bumi yang paling banyak jenisnya. Kode pengenal biasanya berupa huruf SAE yang merupakan singkatan dari society of automotive engineer. Angka yang mengikuti dibelakangnya, menunjukkan tingkat kekentalan minyak pelumas tersebut. Semakin besar angka yang mengikuti kode minyak pelumas menandakan semakin kentalnya minyak pelumas tersebut. Sedangkan huruf W yang terdapat dibelakang angka awal, merupakan singkatan dari Winter. SAE $15 \mathrm{~W}-50$, berarti minyak pelumas tersebut memiliki tingkat kekentalan SAE 15 untuk kondisi temperatur dingin dan SAE 50 pada kondisi temperatur panas. Dengan kondisi seperti ini, minyak pelumas akan memberikan perlindungan optimal saat mesin start pada kondisi ekstrim sekalipun. Sementara itu, dalam kondisi temperatur normal, idealnya minyak pelumas akan bekerja pada kisaran kekentalan 40-50 menurut standar SAE.

Minyak pelumas bekas dihasilkan dari minyak pelumas yang digunakan pada kendaraan dan mesin-mesin. Pada dasarnya minyak pelumas bekas tersusun dari komponen organik hidrokarbon rantai panjang yang sangat memungkinkan untuk menghasilkan produk cair yang bernilai. Minyak pelumas bekas merupakan salah satu sumber polutan yang dapat mengkontaminasi air tanah, dan akan merusak kandungan air tanah, bahkan dapat membunuh mikroorganisme didalam tanah serta minyak pelumas bekas dapat menghambat proses oksidasi biologi dari sistem lingkungan.

Pirolisis merupakan suatu proses dekomposisi termal yang dapat memutuskan ikatan hidrokarbon rantai panjang menjadi hidrokarbon rantai pendek. Proses dekomposisi termal pada pirolisis disebut juga devolatilisasi. Dalam teknologi minyak bumi, pirolisis disebut juga steam cracking dimana hidrokarbon jenuh terpecah menjadi hidrokarbon yang lebih pendek bahkan hidrokarbon tak jenuh.

Katalis adalah suatu zat yang mempercepat laju reaksi kimia pada temperatur tertentu, tanpa mengalami perubahan atau terpakai oleh reaksi itu sendiri. Suatu katalis berperan dalam reaksi 
bukan sebagai pereaksi ataupun produk. Katalis memungkinkan reaksi berlangsung lebih cepat atau memungkinkan reaksi pada temperatur yang lebih rendah akibat perubahan yang dipicunya terhadap reaksi. Katalis menyediakan suatu jalur pilihan dengan energi aktivasi yang lebih rendah. Katalis mengurangi energi yang dibutuhkan untuk berlangsungnya reaksi. Zeolite merupakan salah satu bahan yang dapat digunakan sebagai katalis.

\section{METODE PENELITIAN}

Penelitian ini akan dilaksanakan pada bulan April sampai September 2019. Minyak pelumas bekas yang digunakan berasal dari buangan alat berat pada pertambangan batubara.

\section{Alat dan Bahan Penelitian}

Peralatan dan bahan yang digunakan dalam penelitian ini meliputi picnometer,gelas ukur,corong, neraca analitik, tabung pemanas, distilasi, termometer $\mathrm{Hg}$, tissue, gabus, flash point PM, viscositas kinematic, pour point D 97, batu didih, minyak pelumas, zeolite dan aquadest.

\section{Metode Penelitian}

Persiapan Penelitin :

a) Persiapkan peralatan

b) Nyalakan heater distilasi

c) Tuangkan minyak pelumas kedalam gelas ukur sebanyak $125 \mathrm{ml}$ kemudian tuangkan kedalam labu pemanas

d) Tuang zeolite yang telah diaktivasi sebanyak 0, 1, 2 dan 3 gram, kemudian masukkan kedalam labu pemanas yang telah terisi minyak pelumas

e) Tutup labu pemanas dengan gabus yang telah diberi thermometer

f) Letakkan labu pemanas keatas heater yang telah dipanaskan, kemudian naikkan voltase heater

g) Sambungkan labu pemanas ke kondensor

h) Jaga temperatur kondensor pada suhu 8-10 C dengan air es

i) Ukur banyaknya produk yang dihasilkan

Aktivasi zaeolite dilakukan secara kimiawi dengan prosedur sebagai berikut:

a) Zeolite yang berbentuk bongkahan batu kecil-kecil ditumbuk menjadi serbuk, lalu diayak sehingga ukuran partikel berkisar 40 mesh

b) Zeolite kemudian direndam dalam larutan akuades selama 24 jam

c) Setelah direndam, zeolite disaring dengan kertas saring lalu dikeringkan

d) Setelah zeolite kering lalu dimasukkan ke dalam larutan $\mathrm{NaOH}$ konsetrasi 10\% (w/w) selama beberapa menit lalu zeolite disaring.

e) Setelah zeolite disaring dan dikeringkan, zeolite dioven pada temperature $120 \mathrm{C}$ selama 3 jam.

f) Setelah 3 jam, kemudian didinginkan dan zeolite siap digunakan.

\section{Proses Pirolisis}

a) Memasukkan minyak pelumas bekas kedalam reaktor.

b) Memasukkan katalis zeolite sebanyak 0, 1, 2, dan 3 gram.

c) Memasukkan reaktor/tabung pemanas ke heater kemudian unit kondensor sedemikian rupa hingga tidak ada celah/kebocoran antara saluran gas hasil pemanasan minyak pelumas bekas dan saluran air pendingin/kondensor. Pada reaktor, sebelumnya telah dipasang thermometer untuk mengetahui temperature penguapan yang terjadi.

d) Menyeting temperatur pirolisis pada suhu $320 \mathrm{C}$ 
e) Setelah minyak pelumas bekas dalam reaktor mengalami penguapan maka uap tersebut akan mengalir ke pipa kondensor dan terjadi proses kondensasi yang merubah uap tersebut menjadi cair/produk, amati proses kondensasi yang terjadi selama 1 jam

f) Setelah satu jam proses kondensasi maka selanjutnya adalah mematikan pemanas.

g) Setelah reaktor dingin lakukan perhitungan produk bahan bakar cair yang terbentuk.

h) Produk yang dihasilkan dilakukan analisa sifat fisik seperti seperti IBP, densitas, viskositas, flash point, pour point dan spesific gravity.

\section{Analisis Data}

Setelah proses pirolisis dilakukan, akan didapat data hubungan antara jumlah produk cair yang dihasilkan dengan katalis yang digunakan. Produk cair hasil pirolisis dianalisis sifat fisikanya seperti IBP, densitas, viskositas, flash point, pour point dan spesific gravity dimana hasilnya dibandingkan dengan sifat-sifat bahan bakar yang mendekati.

\section{HASIL DAN PEMBAHASAN \\ Hasil Pirolisis}

Pirolisis adalah dekomposisi kimia bahan organik melalui proses pemanasan dengan sedikit oksigen atau reagen lainnya dimana material mentah akan mengalai pemecahan struktur kimia menjadi fase gas. Pada proses pirolisis minyak yang dipanaskan pada suhu tinggi menyebabkan minyak pelumas bekas terpecah menjadi beberapa campuran gas, cairan dan material padat. Gas-gas yang terbentuk dapat dikondensasikan menjadi cairan. Zat yang memiliki titik didih yang lebih rendah akan akan menguap. Uap tersebut bergerak menuju kondensor (pendingin) sehingga uap yang dihasilkan akan kembali mencair. Proses pirolisis minyak pelumas bekas pertambangan batubara pada penelitian ini dilakukan pada tekanan atmosfer dan pengaturan suhu secara transient. Hasil pirolisis minyak pelumas bekas berupa produk cair hasil kondensasi, residu padat dan uap yang tidak dapat terkondensasi. Gas yang tidak terkondensasi persentase massanya sangat kecil dibandingkan produk cair yang dihasilkan. Residu padat yang dihasilkan menempel dibagian bawah reaktor.

\section{Pengaruh Katalis Terhadap Presentase Produk Cair}

Produk cair proses pirolisis minyak pelumas bekas pertambangan batubaraa mulai dihasilkan pada suhu $190 \mathrm{C}$ dengan variasi jumlah katalis yang digunakan masing-masing 0 gr, 1 gr, 2 gr dan 3 gr. Gambar 1 menampilkan jumlah produk cair yang dihasilkan dari pirolisis minyak pelumas bekas dengan variasi jumlah katalis yang digunakan. 


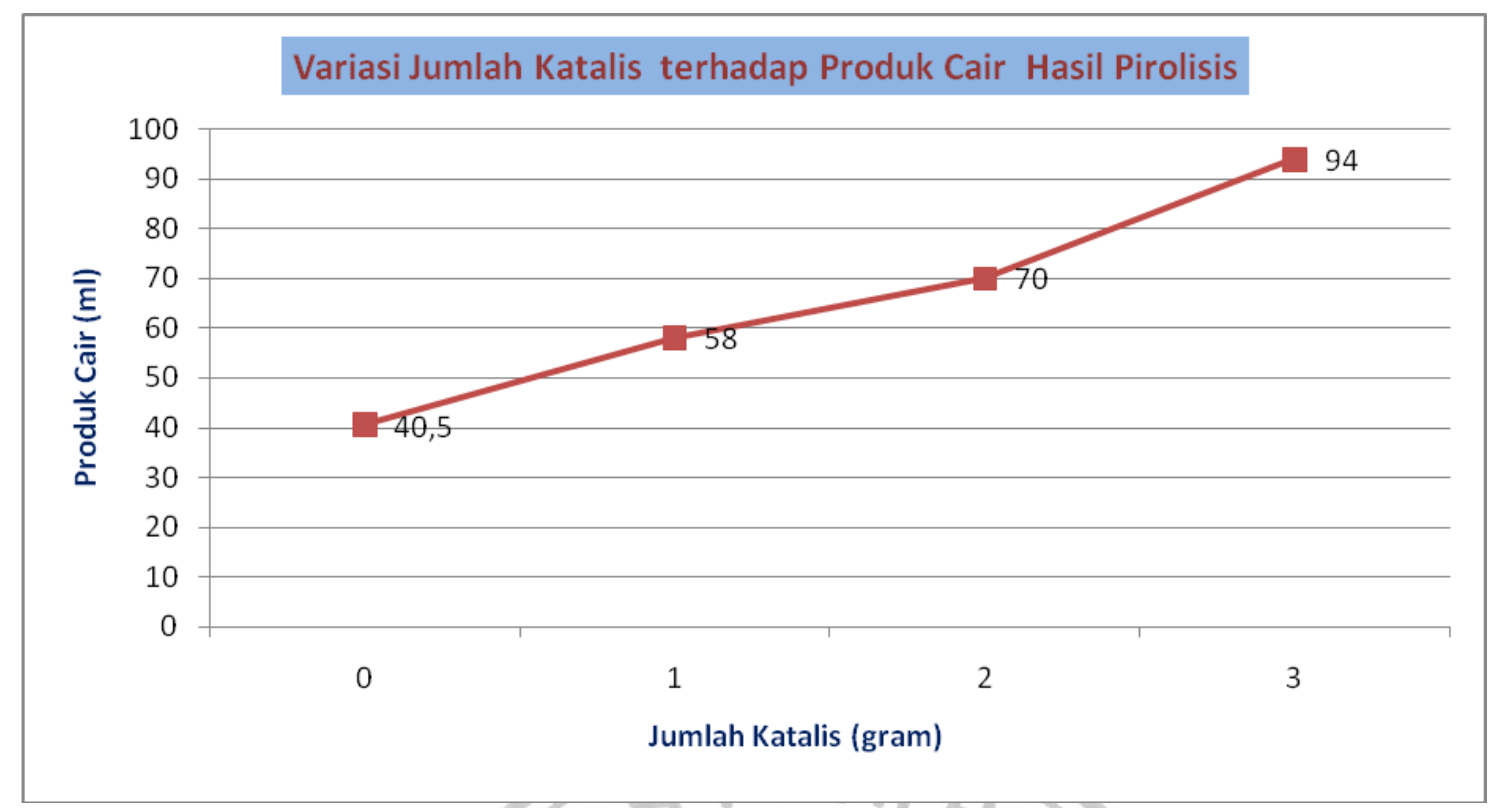

Gambar 1. Grafik Variasi Jumlah Katalis terhadap Produk Cair Hasil Pirolisis

Produk cair yang dihasilkan meningkat dengan bertambahnya jumlah katalis yang digunakan. Produk cair yang dihasilkan sebanyak $40,5 \mathrm{ml}, 58 \mathrm{ml}, 70 \mathrm{ml}$ dan $94 \mathrm{ml}$ untuk massa katalis masingmasing 0 gr, 1 gr, 2 gr, dan 3 gr. Penggunaan katalis sebanyak 3 gr memberikan hasil yang maksimal yaitu sebanyak $94 \mathrm{ml}$ produk cair atau $75 \%$. Pirolisis minyak pelumas bekas yang dilakukan tanpa penggunaan katalis juga menghasilkan produk cair pada suhu 190 C. Namun, jumlah produk yang dihasilkan lebih sedikit jika dibandingkan dengan pirolisis tanpa menggunakan katalis (32\%). Scheirs and Kaminsky (2006) menyatakan bahwa keberadaan katalis mampu memecah ikatan rantai hidrokarbon rantai panjang menjadi hidrokarbon rantai pendek serta mampu mempercepat dekomposisi dan meningkatkan produk cair dari hasil pirolisis. Keberadaan katalis dapat mempercepat pemutusan ikatan atom antar karbon sehingga dihasilkan lebih banyak komponen hidrokarbon ringan dan jumlah produk cair yang dihasilkan menjadi lebih banyak.

Lebih lanjut, Danarto (2010) menemukan bahwa pirolisis dengan katalis zeolit menghasilkan gas dan padatan yang lebih sedikit dibandingkan tanpa katalis. Penambahan katalis juga dapat memperbaiki karakteristik bio oil yang dihasilkan dari proses pirolisis dan dapat meminimalisir produksi wax yang dihasilkan saat pirolisis tanpa katalis pada sampah plastik (Syamsiro, 2015).

\section{Pengujian Laboratorium Produk Cair}

Komposisi minyak pelumas baru yang belum digunakan mengandung hidrokarbon dengan rantai karbon lebih dari $25\left(\mathrm{C}_{25}\right)$. Setelah digunakan, komponen hidrokarbon berubah menjadi kurang lebih $84,42 \% \quad \mathrm{C}_{25}$ dan $16 \% \quad \mathrm{C}_{12}-\mathrm{C}_{25}$ yang dihasilkan akibat pemanasan pada mesin yang memungkinkan perengkahan ikatan antar molekul hidrokarbon. Produk cair hasil pirolisis mempunyai komposisi karbon $\mathrm{C}_{6}-\mathrm{C}_{20}$, dimana $\mathrm{C}_{5}-\mathrm{C}_{11}$ merupakan komponen hidrokarbon volatil bensin (47\%) dan $\mathrm{C}_{12}-\mathrm{C}_{25}$ yang merupakan angka karbon minyak diesel (52\%) (Askaditya, 2010).

Pengujian sifat fisik produk cair minyak pelumas bekas dilakukan untuk mengetahui karakteristik produk yang dihasilkan dari pirolisis minyak pelumas bekas. Pengujian sifat fisik yang dilakukan adalah IBP, densitas, viskositas, flash point, pour point dan spesific garvity. Hasil pengujian selanjutnya dibandingkan dengan nilai standar bahan bakar solar ( Tabel 1). 
Tabel 1. Sifat Fisik Produk Cair Hasil Pirolisis dan Solar

\begin{tabular}{|l|c|c|c|}
\hline \multirow{2}{*}{\multicolumn{1}{c|}{ Sifat Fisik }} & \multirow{2}{*}{ Hasil Uji } & \multicolumn{2}{c|}{ Spesifikasi Solar } \\
\cline { 3 - 4 } & & Standar Pertamina & $\begin{array}{c}\text { Data Standar } \\
\text { Sumber Lain }\end{array}$ \\
\hline IBP, C & 190 & - & 210 \\
\hline Density Produk (kg/ml) & 840 & $815-870$ & - \\
\hline Viscositas $\left(\mathrm{mm}^{2} / \mathrm{s}\right)$ & 0,245 & $2-4.5$ & $1,9-4,1$ \\
\hline Flash Point, C & 56 & Min 52 & 52 \\
\hline Pour Point, C & $<0$ & Max 18 & - \\
\hline Specific Gravity & 0,840 & $0,820-0,870$ & - \\
\hline
\end{tabular}

\section{IBP}

IBP (Initial Boilling Point) adalah pembacaan termometer pada saat tetesan kondesat pertama jatuh yang terlihat pada ujung tabung kondensor. Pada penelitian pirolisis minyak pelumas bekas ini, produk cair mulai dihasilkan pada suhu 190 C. Produk yang berhasil diuap kan pada suhu 190 $\mathrm{C}$ tersebut selanjutnya dikondensasi menjadi cair. Pada temperatur tersebut ikatan antar karbon yang terdapat pada minyak pelumas terputus dan rantai karbon menjadi lebih pendek. Molekul hidrokarbon yang lebih ringan menguap melewati kondensor. Uap panas yang melallui kondesor selanjutnya mengalami kondensasi dan berubah menjadi produk cair.

\section{Nilai Densitas}

Densitas atau massa jenis merupakan kerapatan suatu zat, yakni perbandingan antara massa zat dan volume zat tersebut. Densitas diukur menggunakan piknometer. Sample minyak pelumas bekas memiliki densitas sebesar $870 \mathrm{~kg} / \mathrm{m}^{3}$, hasil pirolisis didapatkan densitas produk sebesar $840 \mathrm{~kg} / \mathrm{m}^{3}$. Massa jenis solar yang dipasarkan didalam negeri memiliki densitas sebesar $815-860 \mathrm{~kg} / \mathrm{m}^{3}$ (SK Dirjen Migas No. 28.K/ 10/ DJM.T /2016). Dengan demikian, nilai densitas produk memenuhi standar densitas solar.

\section{Viskositas}

Viskositas adalah ketidak leluasaan aliran cairan dan gas yang disebabkan oleh gesekan antar bagian cairan tersebut dan menyebabkan kekentalan. Viskositas juga merupakan ukuran resistensi bahan bakar tersebut untuk mengalir. Jika temperatur naik viskositas akan turun sehingga akan lebih mudah mengalir. Viskositas kinematik pada produk cair hasil pirolisis pada suhu $30 \mathrm{C}$ didapat $2,60 \mathrm{~mm}^{2} / \mathrm{s}$ dan pada suhu $40 \mathrm{C}$ sebesar $2,45 \mathrm{~mm}^{2} / \mathrm{s}$. Nilai ini memenuhi batasan viskositas kinematika minyak solar yang ditetapkan pertamina yaitu 4,5 dengan batas minimal $2,0 \mathrm{~mm}^{2} / \mathrm{s}$. Viskositas kinematika menjadi salah satu sifat fisik yang penting karena mempengaruhi kinerja komponen injeksi bahan bakar terutama pada temperatur rendah dimana viskositas mempengaruhi fluiditas bahan bakar. Viskositas yang tinggi akan menyebabkan atomisasi bahan bakar yang tidak sempurna pada semprotan bahan bakar dan menyebabkan ketidakakuratan operasional injektor bahan bakar.

\section{Flash point $56 \mathrm{C}$}

Flash point adalah temperatur dimana suatu bahan bakar membentuk uap yang mudah terbakar jika diberikan pemicu nyala api. Flash point yang rendah menyebabkan masalah dalam penyimpanan bahan bakar. Flash point yang terlalu tinggi menyebabkan bahan bakar susah terbakar pada temperatur rendah atau pada keadaan mesin dingin. Flash point produk cair hasil pirolisis minyak pelumas bekas adalah $56 \mathrm{C}$. Nilai flash point hasil pirolisis ini memenuhi nilai standar spesifikasi solar pertamina yaitu minimal $52 \mathrm{C}$. 


\section{Pour point $<0 \mathrm{C}$}

Pour point / titik tuang hasil pengujian didapatkan nilai $<0 \mathrm{C}$. Nilai ini tidak melebihi batas maksimal minyak solar pertamina yaitu maksimal $18 \mathrm{C}$. Ini menunjukkan, produk cair pirolisis pada cuaca dingin masih dapat mengalir dan dapat dipompa dari tangki bahan bakar menuju mesin.

\section{Spesific Gravity}

Spesific Gravity merupakan sifat fisik bahan bakar yang digunakan untuk menentukan perbandingan udara-bahan bakar yang memasuki ruang bakar yang didasarkan pada berat campuran udara-bahan bakar. Kenaikan spesific gravity akan menyebabkan kenaikan massa bahan bakar yang dikonsumsi. Spesific gravity produk cair hasil pirolisis minyak pelumas adalah 0,840. Nilai ini mememuhi standar untuk bahan bakar solar pertamina yaitu 0,820 dan maksimal 0,870 .

\section{KESIMPULAN}

a. Pemanfaatan minyak pelumas bekas pertambangan batubara menjadi bahan bakar cair telah dilakukan secara eksperimental dengan menggunakan variasi massa katalis zeolite. Pirolisis minyak pelumas bekas menghasilkan produk berupa gas yang dapat diembunkan, gas yang tidak dapat diembunkan dan residu padat. Pirolisis minyak pelumas bekas dengan katalis zeolit menghasilkan produk cair yang paling lebih banyak dibandingkan pirolisis yang berlangsung tanpa menggunakan katalis. Penggunaan katalis zeolite sebanyak 3 gram menghasilkan produk cair tertinggi yaitu sebesar $75 \%$.

b. Sifat-sifat fisik produk cair hasil pirolisis minyak pelumas bekas pertambangan batubara yang meliputi IBP, densitas, viskositas, flash point, pour point dan spesific gravity memenuhi spesifikasi minyak solar pertamina untuk bahan bakar mesin diesel.

\section{DAFTAR PUSTAKA}

Arnoldi, Dwi. 2009. Pemilihan Minyak Pelumas/Oli Kendaraan bermotor. Jurnal austent, 1 (2):26-30 (http:// jurnal.polsri.ac.id/index.php/austenit/article/ download/94/31)

Askaditya, Gama. 2010. Studi Eksperimental Pirolisis Minyak Pelumas Bekas Menggunakan Katalis Zeolit. Universitas Negeri Sebelas Maret. Surakarta

Baso, Prabir. 2010. Biomass Gasification and Pyrolisis : Practical Design and Theory. Akademic Press. Elsevier. Amsterdam

Danarto, Y.C. 2010. Pirolisis Serbuk Kayu dengan Katalisator Zeolite. Prosiding Seminar Nasional teknik Kimia "Kejuangan". Yogyakarta

Demirbas, A. 2005. Recent Advances in Waste Processing Technologies For Upgrading of Synthetic Fuels. Energy Edu. Sci. Technol. Vol 13: 1-12

Kementrian Energi dan Sumber Daya Mineral. 2016. SK Dirjen Migas No. 28.K/10/ DJM.T/2016. Jakarta

Scheirs, J and Kaminsky, W. 2006. Feedstock Recycling and Pyrolisis of Waste Plastic: Converting Waste Plastics Into Diesel and Other Fuels. John Willey and Son Ltd. New York

Supriyanto, Bambang. 2008. Pengaruh Kecepatan Udara terhadap Pembakaran Oli Bekas-Kerosene Menggunakan Air - Atomizing Burner untuk Peleburan Aluminium, Universitas Sebelas Maret . Surakarta

Syamsiro.M. 2015. Co-production of Liquid and Gas Fuels From Waste Plastics. The 4th AUN/SEED- Net Regional Conference om New and Renewable Energy. Hanoi. Vietnam

Zam. 2011. Bioremediasi Tanah yang Tercemar Limbah Pengilangan Minyak Bumi secara In Vitro pada Konsentrasi pH Berbeda. Jurnal Agroteknologi, 1 (2): 1-8 